\begin{tabular}{|c|c|c|c|c|c|c|}
\hline \multirow{4}{*}{ Impact Factor: } & ISRA (India) & $=3.117$ & SIS (USA) & $=0.912$ & ICV (Poland) & $=6.630$ \\
\hline & ISI (Dubai, UAE & $=0.829$ & РИНЦ (Russia) & $=0.156$ & PIF (India) & $=1.940$ \\
\hline & GIF (Australia) & $=0.564$ & ESJI (KZ) & $=8.716$ & IBI (India) & $=4.260$ \\
\hline & JIF & $=1.500$ & SJIF (Morocco) & $=5.667$ & OAJI (USA) & $=0.350$ \\
\hline
\end{tabular}

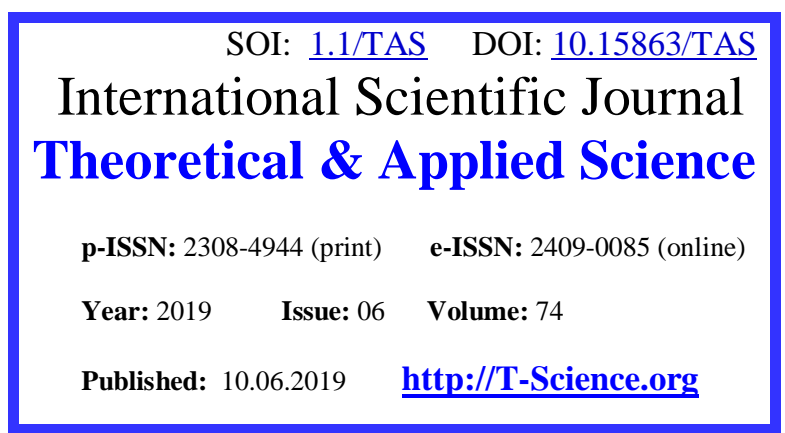

УДК 685:74 519.54.
QR - Issue

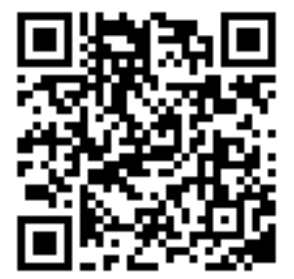

Artur Alexandrovich Blagorodov Institute of Entrepreneurship and Service sector (branch)

DSTU

bachelor, g. Shakhty blaghorodov@list.ru

Dmitri Olegovich Bordukh

Institute of Entrepreneurship and Service sector (branch)

DSTU

bachelor, g. Shakhty bordukh95@bk.ru

Angelina Vladimirovna Kopylova Institute of Entrepreneurship and Service sector (branch)

DSTU

bachelor, g. Shakhty angelinakopylova22121999@mail.ru

Vladimir Timofeevich Prokhorov ISOP (f) DGTU

Doctor of technical sciences, professor of the department "Designing, technology and design", Shakhty prohorov@sssu.ru

Tatyana Pavlovna Lopatenko Isoip (f) DSTU associate Professor,

Department of Natural Sciences, g. Shakhty

\title{
SEARCH FOR EFFECTIVE SOLUTIONS BASED ON THE USE OF DIGITAL PRODUCTION FOR THE MANUFACTURE OF POPULAR AND COMPETITIVE PRODUCTS TO CONSUMERS IN THE REGIONS OF SFD AND SKFO
}

Abstract: the authors analyze the reasons that provoke the production of light industry products that are not in demand by consumers because of its poor quality, because of its non-compliance with the requirements of GOST And technical regulations. Today, there are all prerequisites for import substitution: the adopted customs barriers, and the imposed sanctions that limit the presence in the domestic markets of demand for branded products from leading foreign manufacturers, but there is no positive result yet. The authors suggest remembering that it is necessary to educate domestic producers a sense of personal responsibility to their consumers for unsatisfactory results, not to nod at the circumstances, to be patriots of their country and to please their consumers with the filling of markets with competitive and popular products. Again, there are all the prerequisites.

Key words: quality, demand, innovative technological solutions, competitiveness, import substitution, professionalism, culture of production, digital production, customer demand, professional responsibility, quality system, high-tech economy, personal responsibility of the head.

Language: English 


\begin{tabular}{|c|c|c|c|c|c|c|}
\hline \multirow{4}{*}{ Impact Factor: } & ISRA (India) & $=3.117$ & SIS (USA) & $=0.912$ & ICV (Poland) & $=6.630$ \\
\hline & ISI (Dubai, UAE & $=0.829$ & РИНЦ (Russia & $=0.156$ & PIF (India) & $=1.940$ \\
\hline & GIF (Australia) & $=0.564$ & ESJI (KZ) & $=8.716$ & IBI (India) & $=4.260$ \\
\hline & JIF & $=1.500$ & SJIF (Morocco & $=\mathbf{5 . 6 6 7}$ & OAJI (USA) & $=0.350$ \\
\hline
\end{tabular}

Citation: Blagorodov, A. A., Bordukh, D. O., Angelina, V. K., Prokhorov, V. T., \& Lopatenko, T. P. (2019). Search for effective solutions based on the use of digital production for the manufacture of popular and competitive products to consumers in the regions of SFD and SKFO. ISJ Theoretical \& Applied Science, 06 (74), 68-81.

Soi: http://s-o-i.org/1.1/TAS-06-74-4 Doi: crossef https://dx.doi.org/10.15863/TAS.2019.06.74.4

\section{Introduction}

In the USSR in the $50-80$-ies of XX century formed a quality management system, little inferior to foreign experience. This system was continuously improved in the light of positive and negative experiences until the end of the 1980s. Everything started to fall apart in the waves, the born of "new political thinking". Finally, the democratic tsunami of the nineties swept over the system policy in relation to the organization of quality management. The crisis and "shock therapy" removed the urgency of the problem for the next decades. Causes of deactualization of interest to quality are in plain sight:

- the achievements of the quality management policy of the Soviet period were associated with the peculiarities of the socialist type of planning, built on the principle of Directive, in which, unlike indicative planning, economic stimulation was subordinated to political goals directly. When the administrative and team practice of enterprise management became unnecessary, together with it the practice of quality management went down in history;

- it is no secret that with the collapse of the USSR Russia's future looked very differently "systemically". The Russian economy was not trying to be built into the world production, but to be built in the interests of the existing architecture. We were given a place of producers and suppliers of raw materials, mainly of natural origin. The quality of such products is not due to production. The quality of production depends on the amount of added value the less costs, the greater the difference between price and cost, higher profits. Production of a barrel of oil in Qatar and Saudi Arabia costs significantly less than in Russia. Having refused to control the market, the state has consistently freed itself from the obligation to control the production process. And this happened despite the fact that the bureaucracy and the cost of its maintenance increased by an order of magnitude. The very concept of "quality management" was lowered to the level of "quality control", after which each manufacturer could manage the quality itself. In the end, the quality is simplified to technical regulation;

- the quality of production and the product of production are functionally related to the quality of the market, the quality of the market, in turn, depends on the customer's willingness to purchase products marked with a quality mark. A quality product is in demand under two mandatory conditions: the effective demand of the mass buyer and the integrity of the seller. Neither one nor the other in the domestic market. Even in boutiques and luxury stores the buyer does not feel guaranteed to be protected from counterfeit products and deceiver manufacturer. The market is an integral part of society. The order in the market reflects the state of society, and the manufacturer focuses on the state of the market. For him, the barometer is not the national interest - market opportunities. The market is the driving force of production. If the culture of the market really outstripped the culture of production, the objections to the consumer approach to production would be reduced to a minimum. In fact, the culture of the market in Russia laid not producers and especially not consumers with their skinny wallet. Our market has been dominated from the very beginning by intermediaries and speculators. Under them built and legislation that allows a lot of different interpretations of the actions and the number of opportunities to avoid criminal liability that Ostap Bender's boast of four hundred ways to circumvent the criminal code seems vaudeville humor. Before the onslaught of intermediaries and speculators, very often in tuxedos from well-known fashion designers, traditional Russian troubles receded into the background and began to work for new leaders. Quality management in this situation has become a manipulation of quality in the interests of the owners of the market. Until we restructure the relations in the sphere of exchange of goods for money and raise the purchasing effective demand to the possibility of choosing a quality product, we have a quality problem will remain at the level of economic theory.

The manufacturer is not currently interested in producing a quality product. "Sheepskin is not worth the candle" - the costs are high, the cost of products will grow, the real price will significantly increase the intermediary and the seller. As a result, the market of such a product "will not digest" and the manufacturer will be struck by the deadly disease No. 1 by E. Deming. In a limited - clearly scanty for Russia scale quality things are guaranteed to make, produce, but nothing to do with the situation in the production of the given practice is not, it is exclusive.

Attempts by the Executive in the zero years to activate interest in TQM had success again local and temporary. In Soviet times, the top team looked logical and forced to reckon with them. The changed from socialist to capitalist reality reacted to these initiatives sluggishly, without any enthusiasm, it is possible to tell purely enlightening, but not practically. Not surprisingly, to peel off the soles of shoes were added to the faulty rocket not capable of rising into space.

To the above-mentioned causal factors, we add the long-standing disease inherited by the Russian management from the socialist period. "The creation of a quality system in Russia stumbles upon another 


\begin{tabular}{llllll} 
& ISRA (India) $=\mathbf{3 . 1 1 7}$ & SIS (USA) $=\mathbf{0 . 9 1 2}$ & ICV (Poland) & $\mathbf{= 6 . 6 3 0}$ \\
Impact Factor: & ISI (Dubai, UAE) $=\mathbf{0 . 8 2 9}$ & PUHЦ (Russia) $=\mathbf{0 . 1 5 6}$ & PIF (India) & $=\mathbf{1 . 9 4 0}$ \\
& GIF (Australia) $=\mathbf{0 . 5 6 4}$ & ESJI (KZ) & $\mathbf{8 . 7 1 6}$ & IBI (India) & $=\mathbf{4 . 2 6 0}$ \\
& JIF & $\mathbf{1 . 5 0 0}$ & SJIF (Morocco) $=\mathbf{5 . 6 6 7}$ & OAJI (USA) & $\mathbf{0 . 3 5 0}$ \\
\hline
\end{tabular}

problem typical of our country, write B. S. Aleshin and co-authors. It is that the instructions are written for someone, not for a particular employee. Therefore, a simple violation of the instructions has become a common situation. This is fundamentally unacceptable in enterprises using a quality management system." Not trusting top management to solve this problem, B. S. Aleshin is looking for support at the corporate level - "... in the preparation and development of the quality system in Russia, it is useful to extend the scope of the problem and to consider the establishment of a system of corporate standards that support the quality system".

B. S. Aleshin is a well-known specialist in the field of management, he held the highest positions in the Russian government and knows the matter from the inside. He needs to know the story of the training of managers, leaving the roots in Soviet times. A. G. Aganbegyan tried to solve it when he was the Director of the Institute in the USSR Soan system. He did it very seriously, initiating the creation of the Board of Directors of the largest enterprises of Siberia. Outwardly, the question looked simple: the economist-Manager (then overseas "Manager" was not used) is a "free artist", or his professional training should be built as an add-on to the production-oriented Foundation, ie, first vocational training, only then economic education. A formal solution to the problem was available in departmental universities, where the name of the departments involved economic and industrial components, for example, in the universities of the Ministry of education the Department was called "Economics in transport".

Discussion of A. G. Aganbegyan ended expected - most thought it was appropriate economic training be linked to productive characteristics. Only in this way it can be given the necessary level of specificity. The reforms of the 1990s abolished the developed scheme, brought the training of managers in accordance with the procedure established by them, whose economy has defined as a benchmark. The illogicality of economic policy was not concealed, on the contrary, praised. Absolutization in science is not acceptable as a brake of scientific creativity. However, recognizing the need for a transition phase, economists who came to power in the teacher took those who knew from history books about what to do during the transition. Wanted to "one-two" to be in a post-industrial economy, pass a developed industrial. With all the defects of socialist industrialization, it has become an objective historical fact for two five-year plan, and for five "five-year" even reindustrialization failed to implement. As a result, we returned to the previous logic of development. The military-industrial complex and Roscosmos made industrial progress locomotives, hoping that they will pull the development of the rest of the industry. But, not being confident in the ability of others to cope with new tasks, because they do not fulfill the old ones, the government called on the MIC to expand the production of a range of mass consumer goods in order to meet the household needs of the population.

One of the basic rules of quality management experts believe the return to the starting position, if the process did not go. Therefore, the restoration of the previous model of economic recovery should be recorded as an asset of the government. To this would still attach the principle of consistency in the implementation of the socialist imperative of the unity of theory and practice. Viperoni of the Soviet Politburo decisions are not developed. They have agreed to and accepted. Draft decisions were prepared by professionals, consultants, "subcontractors" and "initiators", they had scientists of the USSR Academy of Sciences and the most successful production managers. Random man in the industrial departments of the regional party, the CPSU Central Committee could get only once Stirlitz. Party and people's control was established. Naturally not perfect, but effective. The decomposition started when with the arrival of Gorbachev and his henchmen have declared themselves and scientists, and skilled production workers, and prophets, having lost the critical ability. Euphoria feelings muddied mind. Dialectics in management gave way to the desire to find an existing example, which gave rise to the rebirth of dialectical thinking, built on the basis of historical specificity of true knowledge, in the primitive eclecticism of $\mathrm{E}$. Gaidar and $\mathrm{K}^{\circ}$.

The liberal abstract fantasy was washed away by A. Aganbegyan's natural aspiration to combine scientific knowledge of Economics with common sense and practically verified experience.

The criterion of the level of subject-oriented knowledge is the quality of management of the relevant area of objective reality.

The paradox of economic management lies in the specifics of the movement of social production. To operate competently, we need a theoretical, hence, the General scientific knowledge produced by Economics, but control is almost always accounted for separately taken enterprise, no economic chain. In this sense, economic management is already an art, it is akin to medicine, the principle of which is also externally simple: we define the disease, but treat the patient, so the algorithms are good in the theoretical training of the doctor, but they are limited in the treatment of the patient. Something close to economic management and fashion. High fashion determines the style, color preference, the specifics of the shape of the product, the nature of its combination with finishing and accessories, the type of material. As for the individual product, its specificity is approved by the customer, based on the Constitution and financial 


\begin{tabular}{llllll} 
& ISRA (India) $=\mathbf{3 . 1 1 7}$ & SIS (USA) $=\mathbf{0 . 9 1 2}$ & ICV (Poland) & $\mathbf{= 6 . 6 3 0}$ \\
Impact Factor: & ISI (Dubai, UAE) $=\mathbf{0 . 8 2 9}$ & PUHЦ (Russia) $=\mathbf{0 . 1 5 6}$ & PIF (India) & $=\mathbf{1 . 9 4 0}$ \\
& GIF (Australia) $=\mathbf{0 . 5 6 4}$ & ESJI (KZ) & $\mathbf{8 . 7 1 6}$ & IBI (India) & $=\mathbf{4 . 2 6 0}$ \\
& JIF & $\mathbf{1 . 5 0 0}$ & SJIF (Morocco) $=\mathbf{5 . 6 6 7}$ & OAJI (USA) & $\mathbf{0 . 3 5 0}$ \\
\hline
\end{tabular}

capabilities. Usually believe that fashion imprisons, disagree. Mod provides just enough freedom of action in the specified parameters. It experiences the cultural development of the consumer's personality. There is freedom and the Manager of the enterprise, including in determining the attitude to the quality of products. The dream of the Manager to get quality by reducing costs, the dream is understandable, because otherwise you have to raise the price of implementation, which is wrong from the point of view of the theory of quality management. The authoritative Japanese specialist in management I. Ishikawa has repeatedly said that it is immoral to talk about raising prices while improving product quality, since improving quality is associated with stabilizing production, reducing defectiveness, costs, and, consequently, with reducing costs and prices. According to I. Ishikawa, the price increase is justified to judge only when the consumer receives a product of a new technical level.

Given the poor organization of the transition period to a modern high-tech economy, aggravated by the recession on a global scale and the Western policy of sanctions against Russia, it is hardly realistic to count on the professional responsibility of a particular manufacturer for the quality of products. Morality was born before commodity production, but then economic development put morality under its control, securing a new relationship ideologically. Moral development in novels is controlled by the internal forces of the characters. In Economics, morality exists like a jewel in the grip of a ring. Why the ISO standards focus on three points of application of forces is the responsibility of the head, lower costs, and personnel policy? There are three "Golden truths" of quality policy in quality management:

- ignorance is the root cause of all misfortunes in management, first of all in the economy;

- quality is a source of income, as it is associated with the reduction of production losses, in addition, it guarantees economic stability, improves the image;

- careful policy in relation to professionally trained personnel, such people are the main wealth of any production.

Rules apply when there is no reason not to observe them - our own peril each violation. We have, in terms of selective control over the rules, rare manufacturers follow the rules, much more act on the concepts, that is, under the cover of the imperfections of the rules and agreements with officials. And here we can formulate the essence of the political moment, as the leaders liked to say not very long ago. So, what do we have?

First, it is no coincidence that economic theory was detached from politics, political economy was neutralized in economic science. God - God, Caesar Caesar. Very much Gaidar and oligarchs liked American economic liberalism, and they reflected it specifically. Freedom of enterprise was accepted "with a Bang", and about the American draconian measures for violation of the rules of economic activity forgot to tell the people. It was not profitable. Remember the steel only after all divided, and there was a question about the redistribution of the products of privatization.

In an effort to clear the economic theory of the political burden was hidden practical, managerial component. Economic management was separated from the subject specifics of production to be as in theoretical mechanics, physics, chemistry. The next step after the abolition of political economy and priority in the management of production of its substantive focus was the ascension of economic management as a universal factor.

Economic managers have become lawmakers in the development of production. In Russia in the 1990s, a lot of economic advisers and consultants came to Russia, almost the main financial speculator Soros became more active. The question is, why all this was necessary and who benefits? The answer is not so difficult - these changes provided a cover for the transition from a policy of quality management to a policy of quality manipulation. Quality parameters began to be determined by economic managers, of course, based on management interests. K. Marx called the attempt of the economist Proudhon to understand the philosophical foundations of poverty "poverty of philosophy". Liberal economists have stepped on the same "economic" rake as their French predecessor. The result was the same. Having removed the subject certainty, economists - managers restored scholastic philosophy of "realists". Instead of moving towards the concreteness of true knowledge, they absolutized the abstraction of General ideas. Economic science is designed to reconstruct the objective, subject-specific reality, and not to be a manufacturer of easy - to-calculate knowledge. So functions of science and philosophy were interpreted in the Middle ages by theologians. However, it seems that there is a special interest in such a status of science, otherwise how to explain the departure from the objectification of the criteria of scientific assessments.

"Quality" is a philosophical category, which together with "quantity" forms a dialectical pair, that is, they are interdependent. In one of our publications we have identified three fundamental features of "quality»:

- "quality" is a system of defining properties of the phenomenon;

- in the definition of "quality" is always implicated in the number of one of its manifestations - integrity, intensity; 


\begin{tabular}{llllll} 
& ISRA (India) $=\mathbf{3 . 1 1 7}$ & SIS (USA) $=\mathbf{0 . 9 1 2}$ & ICV (Poland) & $\mathbf{= 6 . 6 3 0}$ \\
Impact Factor: & ISI (Dubai, UAE) $=\mathbf{0 . 8 2 9}$ & PUHЦ (Russia) $=\mathbf{0 . 1 5 6}$ & PIF (India) & $=\mathbf{1 . 9 4 0}$ \\
& GIF (Australia) $=\mathbf{0 . 5 6 4}$ & ESJI (KZ) & $\mathbf{8 . 7 1 6}$ & IBI (India) & $=\mathbf{4 . 2 6 0}$ \\
& JIF & $\mathbf{1 . 5 0 0}$ & SJIF (Morocco) $=\mathbf{5 . 6 6 7}$ & OAJI (USA) & $\mathbf{0 . 3 5 0}$ \\
\hline
\end{tabular}

- reflecting the subject diversity of the world, the quality reproduces the objectivity of the difference of phenomena, it is structured.

"Quality management" - the concept of political economy, it allows the variability of development, but within the objectivity of the quality characteristics. Manipulation of quality is a definition of quality characteristics free from actual characteristics in General, theoretical and particular, practical scales. In economic theory, there was no specific procedure for estimating quality costs until the 1950s. The "traditional approach to determining the "optimal" cost of quality" prevailed. $100 \%$ compliance of the product TU was considered unattainable, so the price of quality laid in after the purchase prospect. It was believed that the consumer's expenses for the operation of the goods are inversely proportional to the quality of the goods. They decrease as the quality of the goods, striving to zero. The concept of "optimal quality level" appeared. It corresponded to a minimum of quality cost for the supplier and the consumer. Total costs were defined as the sum of costs of the producer and the consumer.

The new economic reality was formed in the 1970s under the direct influence of the scientific and technological revolution. Increased technical complexity of the product, increased warranty period. These changes forced to abandon the simplified model of determining the cost of quality. The concept of quality cost was born, based on the reduction through more rational financing of quality costs and reducing the total cost of production of the product. The economy tried to make economical. The emphasis in quality management has shifted towards the solution of common problems of production development and its standardization. G. Taguchi generally called the quality measure its cost and gave the following calculations: one shirt washing costs 250 yen, usually during the service the shirt is washed 80 times. The cost of Laundry is 20000 yen. If they can sew a shirt that is crumpled and dirty twice as slowly, the consumer's savings reach 10,000 yen. Suppose a new shirt will cost the manufacturer 1,000 yen more, and the sales will increase by 2,000 yen, the manufacturer will receive a profit of 1,000 yen, the consumer will benefit 8,000 yen. Society will also have savings of 9,000 yen plus a reduction in environmental costs, as there will be less waste from washing.

We are not against the manipulation of quality. Within certain limits, this forced measure testifies to the limitations of cognitive and other opportunities. The theory should not be conservative, but quality manipulation is a tactical level of management as opposed to the strategic value and significance of quality management. Manipulation is one of the management tools, and it must remain a private, changing business in the quality management system.
The second thing to keep in mind when analyzing the prospect of private self-quality control. The private initiative is conditioned by the General political and economic situation. Socialism could be built in a single country, to ensure the competitive ability of socialism was in this historical time impossible. Capitalism is still strong. The same situation awaits private producers. He will release a quality product. Will it be able to work steadily in an environment that is not ripe for such practices.

A quality product is not enough to be able to produce. It should be in demand by a mass buyer, and this situation is already a socio-economic policy. Quality products want to have everything and always. Only - this is an abstract desire. It exists as a dream, a fairy tale. Only as the abstract wishes acquire the status of concreteness of real opportunities will favorable conditions for the priority of "good taste", and the buyer will look for a quality product, and not look with envy in the basket of a rich but obvious minority. In the relations of the manufacturer with the buyer also has its own fields of Higgs. In nature, passing through them, the particles are endowed with mass and turn from energy particles into "real" particles. In the market of goods, the product passes through the fields of sellers of various ranks and acquires an unreal price, which is advertised as a real, appropriate quality. Until the domestic market is brought to a normal market state, which will have to wait a very long time, there will be no interest in the production of quality goods. It is quite acceptable to believe that among Russian manufacturers there are many honest entrepreneurs who have a sincere desire to feed, clothe and put on their fellow citizens as best as possible. Only who will allow them to do it. The market rejects them as "violators of the Convention". Legislators will pass laws in accordance with the order and price of lobbying - it exists legally; officials will make their comments through recommendations, instructions, etc. And in the market, as if in medieval Baghdad, everything will be calm again.

Of course, there is a certain niche in our market, which is used by the most respectable part of the middle class. The niche is insignificant because of the thin social stratum and its instability in the conditions of volatility of economic development. Nevertheless, this sector is, and under its requests manufacturers of quality products, for example, sausages for 1500 rubles per kilogram, shoes for 5 thousand or more, costumes from 15 thousand, also exist. But what does this market exclusive have to do with the characteristics of our economy as a whole? Is it, is thus an exception to the rule that only confirm. The problem of the status of the manufacturer of quality goods - the national scale and the potential of individual, relatively prosperous STRATO, refers to it 


\begin{tabular}{llllll} 
& ISRA (India) $=\mathbf{3 . 1 1 7}$ & SIS (USA) $=\mathbf{0 . 9 1 2}$ & ICV (Poland) & $\mathbf{= 6 . 6 3 0}$ \\
Impact Factor: & ISI (Dubai, UAE) $=\mathbf{0 . 8 2 9}$ & PUHЦ (Russia) $=\mathbf{0 . 1 5 6}$ & PIF (India) & $=\mathbf{1 . 9 4 0}$ \\
& GIF (Australia) $=\mathbf{0 . 5 6 4}$ & ESJI (KZ) & $\mathbf{8 . 7 1 6}$ & IBI (India) & $=\mathbf{4 . 2 6 0}$ \\
& JIF & $\mathbf{1 . 5 0 0}$ & SJIF (Morocco) $=\mathbf{5 . 6 6 7}$ & OAJI (USA) & $\mathbf{0 . 3 5 0}$ \\
\hline
\end{tabular}

as the fate of passengers fleeing in a boat, after what made the storm with their big ship.

We must remember that they have a market for more than three hundred years. During this time, there was a balance of market factors, and manufacturers have adapted to it. Perhaps the correlation of factors and is not perfect, but it reflects the objective market position of the manufacturer, the seller and the buyer. About our market, we said not all, but the main thing highlighted. We have the power in the market from intermediaries and speculators, often appearing in one person. Corrupt officials are connected with them. Therefore, the proportions of our market look different. Especially in terms of the cost of products sold. This part is a Klondike for everyone who feeds on the market, and a headache for real workers. Just because of of its benefits no one refused. Without market regulation, no good intentions will find a quality road to the buyer, because we know where this road leads. And confirmation of all this drinking the fact of irresponsible on the verge of a criminal offense the attitude of producers to their duties, namely, the results of the inspection of trade inspection of the quality of sewing school clothes

For sewing school clothes should be used fabrics made of natural fibers, such as wool, linen, cotton. These fabrics are the most hygienic, have high hygroscopicity and good thermal control properties." According to the study, of the 98 manufacturers of school pants products only 14(!) meet the quality mark, is safe for health according to the requirements. Of the 30 manufacturers of shirts 28 had violations".

Hardly anyone from the devoted to the state of the domestic light industry, expected other results. It is not so much the depressing statistics as the comments of a specialist addressed to the consumer of garment production that amazes. Specialist through a journalist advises: "If the label does not contain information about the manufacturer - its name and location, fabric composition, release date - this is a reason to think (!) " so I want to ask the unknown, but responsible for the status of the interlocutor correspondent: "And the presence of this information can be perceived as a guarantee?" It is also significant that, judging by the lack of continuation of this test, all subjects of relations were in their interest. Checking - reported on the done work on preparation for the all-Russian day of knowledge, checked, having shaken off some awkwardness that didn't get to a track of national movement for a General holiday, continued to do everything as did before control check and during it. For unscrupulous and irresponsible manufacturers, regardless of what they produce boots or missiles, the main thing is the triumph of bureaucracy, with which they will always find enough in common not to interfere with each other to live by known concepts.
The transition to self-regulation of technical characteristics is really possible within the boundaries of objective quality parameters only in the presence of two conditions:

technologies;

- development of modern production

- the developed high professional culture, the system-forming factor of which is the personal form of responsibility.

Of course, non-state control over production, a kind of people's control, should be added to the basic conditions. The onf may be the center of such popular supervision, but there is a danger of its party registration. The real power of the onf lies in the status of an organization independent of inter-party relations, directly subordinate to the President. Top management, unfortunately, has gained experience in taming those who show independence, although in Russia, as in most Russian regional formations, there are all necessary conditions for the development of production in the national interest. If somewhere something is not enough, it does not serve as a basis for recession and recession.

In the mid-2010s, the country found itself in an economic situation similar to the late 1920s - early 1930s. Then the question arose: to be or not to be a new social order, the desired people (for the "chosen" always adapt to any situation). The answer was not hidden in the labyrinth, and L. M. Kaganovich did not need Ariadne's thread to get to the secret source in search of a solution to the problem. He needed the chief's blessing. And Stalin agreed that "personnel decide everything." From ourselves we will specify "professionally prepared and politically responsible for result". The explanation is important, because democratic transformations in Russia miraculously removed the first professional responsibility for obvious defects in politics.

Policy has always been understood by everyone as an activity in the interests of the state. Political responsibility in a democratic society is the ultimate expression of professionalism. The failure to deliver on political promises and declarations is either a failure to engage in politics or to use political governance in private interests. 85 years ago the obvious for consciousness and was deceptive on practice. In vain, speaking of cruelty IV. Stalin, forget that every miscalculation in politics affects the situation of the people, not politicians, managers, consultants, advisers.

In the interests of restructuring the economy to increase the share of added capital in commodity production - in fact, modern industrialization - it is necessary to begin not with economic and not with scientific and technical actions - with a political Renaissance. Of course, modern times require different tools than those of the second half of the 


\begin{tabular}{llllll} 
& ISRA (India) $=\mathbf{3 . 1 1 7}$ & SIS (USA) $=\mathbf{0 . 9 1 2}$ & ICV (Poland) & $\mathbf{= 6 . 6 3 0}$ \\
Impact Factor: & ISI (Dubai, UAE) $=\mathbf{0 . 8 2 9}$ & PUHЦ (Russia) $=\mathbf{0 . 1 5 6}$ & PIF (India) & $=\mathbf{1 . 9 4 0}$ \\
& GIF (Australia) $=\mathbf{0 . 5 6 4}$ & ESJI (KZ) & $\mathbf{8 . 7 1 6}$ & IBI (India) & $=\mathbf{4 . 2 6 0}$ \\
& JIF & $\mathbf{1 . 5 0 0}$ & SJIF (Morocco) $=\mathbf{5 . 6 6 7}$ & OAJI (USA) & $\mathbf{0 . 3 5 0}$ \\
\hline
\end{tabular}

1930s, but the essence must be invariant. Political efficiency is the highest criterion of professionalism. To interpret this conclusion is better from the opposite. The actual reality didn't reach the declared changes - resignation of managers with the subsequent public characteristic depending on specific conditions and the sizes of discrepancy.

In Soviet times, was distributed to party slang "to put in a responsible position"! No one really knew what to do and how to do it, but everyone knew if you do not perform, it will be bad. For some reason, our responsibility was shifted to the market. Responsibility for the implementation of specific political directions, losing a personalized look, ceases to be a responsibility. The Duma is not responsible for anything. The government is responsible to the President and the Duma. The President is solely responsible to the people. Hence only worthy of a rating of national survey. Undoubtedly, the President was helped By his Patriotic policy - consistent, active. But, it seems that the main factor, though not obvious, the popularity of the President, unlike all those in power, is his practical capacity, motivated by high political responsibility.

Unfortunately, while the knots tied by economic incapacity and impunity will be untied by the President, and those responsible for solving the problems facing society will continue to openly delay time, hiding behind the uncertainty of the interpretation of modernization, our General task "to get off the dependence on raw materials" $-55 \%$ of tax revenues, will not be solved.

Personification of responsibility does not mean finding someone who is responsible for everything. Personification implies delegation of responsibility for obtaining the desired result. Here it is essential to realize that "team" is not a company of like-minded people, colleagues, partners; "team" is a chain of responsible, due to the specifics of the object and the problems of its modernization. Responsibility for the result should not be smeared in the bowels of the team. Responsibility even for the team result always has a personal expression, which our high managers do not want to recognize. It is this desire - to "push" everything on the specifics of the control object, the unpredictability of demand, the volatility of the currency, the incomprehensibility of changes in tariffs, etc., that can explain the pressure "from above", with which we are proved that management is a professional direction, not an add-on the subject originality and systemic position of a certain production.

A curious fact, however, not from the history of "light" industry. D. Mendeleev in the early XX century was instructed by the Government to deal with the secret of modernization of gunpowder in Germany. Without direct access to German technology, the chemist requested monitoring of the movement of freight trains in those places where gunpowder is produced with tracking of the beginning and end of routes. On the basis of the information he deciphered the German recipe and developed recommendations for the Russian Government. If he had been a pure economist, a modern top Manager, the result would have been completely different. It would become entangled in the statistical and financial calculations of expenditure-income, moving away from the political, scientific and technical components. The most serious methodological mistake is to reduce economic policy to economic analysis.

Economic science emerged and developed in the context of politics as political economy. Today, economists in politics are guided not by political economy, but by Economics in politics. Instead of investing in the development of production, they hide money in foreign banks, reduce funding for education and self-education, increase the number of the poor, do not index pensions, refuse to help farmers, etc. the "Manila" nineties replaced the "buns" of the tenth.

The main and invariant superiority of Russia lies in the geographical position, combined with the absence of the danger of overpopulation of our space due to natural growth. We have a natural and solid margin of safety for centuries. Instead of pressing the past for irrationality in politics and Economics, we should pay tribute to our ancestors who managed to gather Russia and the peoples around Russia. What worries me is not so much the decline in production, the squandering of what has historically manifested its national specifics, folk traditions, as the possibility of losing the labor talent of the peoples of Russia, the systemic inefficiency of economic policy.

Progress does not happen without retreats, slowdowns, recessions. The policy is designed to help overcome obstacles to development through active, targeted actions. Politicians should stay ahead of the economic movement and guide it, stimulate domestic economic factors with political levers, and clear economic paths to efficient production. Instead, politicians continue to tie development plans to the price of oil, the ruble size of the European and American currencies, citing integration trends in the world and globalization.

The integration of transnational relations is an objective reality, but for all its objectivity, it does not deny the specifics of national economic advancement. Moreover, integration is objectively designed to promote national development. Why can't we do it the way it's supposed to be? This question arises from a logical comparison of the policy in the field of strengthening the defense capability, the restoration of the international authority of the country in the most difficult circumstances of the formation of a new 


\begin{tabular}{llllll} 
& ISRA (India) $=\mathbf{3 . 1 1 7}$ & SIS (USA) $=\mathbf{0 . 9 1 2}$ & ICV (Poland) & $\mathbf{= 6 . 6 3 0}$ \\
Impact Factor: & ISI (Dubai, UAE) $=\mathbf{0 . 8 2 9}$ & PUHЦ (Russia) $=\mathbf{0 . 1 5 6}$ & PIF (India) & $=\mathbf{1 . 9 4 0}$ \\
& GIF (Australia) $=\mathbf{0 . 5 6 4}$ & ESJI (KZ) & $\mathbf{8 . 7 1 6}$ & IBI (India) & $=\mathbf{4 . 2 6 0}$ \\
& JIF & $\mathbf{1 . 5 0 0}$ & SJIF (Morocco) $=\mathbf{5 . 6 6 7}$ & OAJI (USA) & $\mathbf{0 . 3 5 0}$ \\
\hline
\end{tabular}

world architectonics with the fact that from year to year the Russians are watching and fully feel themselves in the rest of the economy - The second "presses on the gas and brakes" at the same time.

The protracted recession in the Russian economy has: two ways of explaining. The first - the people have lost the ability to work well, wasted "human capital", the second - the managers are helpless. The media claim that politicians know their business, keep events under control, take the necessary measures and promise changes for the better in the near future. Therefore, the reason is the poor performance of the performers and the unfavorable global situation.

How naive do you have to be to plan economic policy, based on sincerity, selflessness, sympathy of competitors? The Russian President has long said that our Western partners do not want to strengthen Russia, they need an obedient Russia, such as the Baltic republics, formerly part of the USSR. I do not want to grieve politicians responsible for the economy, but, following Aristotle, forced to state: "Friends in the East, too, on his mind" - in the sense of "Plato is my friend, but the truth is more expensive." They will help us as they benefit from such assistance.

It is time to understand that all economic and political unions in the modern world are an attempt to achieve national gains in the environment of transnational relations, i.e. partners can be counted on as long as they benefit from this cooperation. The conclusion is that it is necessary to face your own economy. Only in this way, albeit with great stress, will be able to solve their problems. For example, there are no objective reasons that would justify the decline in production in light industry for a quarter of a century.

Light industry, closely related to agriculture, is really dependent on the work of the latter. Only such interaction should be approached historically specifically, based on scientific and dialectical analysis. There are old meteorological accounts showing that out of 10 calendar years in Russia 5 are unfavorable for the development of agricultural production $(2+3$ and $3+2)$. The definition of the fiveyear plan as a planning measure was based on this pattern.

The problems of agriculture and light industry are not in their specifics, they have always been political. In the US, Europe, farmers have a lot of our problems. The difference is that there the farmer is a national problem among the most important, basic. Its consideration is relevant to the existence of politicians. On how a policy contributes to the resolution of the estimated public policy. A farmer and a politician are bound by economic policy. They balance on one tight economic tension "rope" of viability.
There is nothing similar in Russia. Let us recall the history of the last Ministers of agriculture. In the USSR there was a Ministry of light industry, which emphasized the importance of the industry. What prevents in terms of import substitution and declarations of importance to develop their own production to restore equality in industrial management. "Calico land" without the light industry is still that the native nature without the birch trees or lyrical poetry without creativity Esenin.

Reformers of the 1990s, the fate of the Fatherland and the domestic industrial identity least worried. They built their business on the ease of maximum profit and placed the walrus away from the land of their ancestors. Light industry has traditionally been a difficult problem for management. Managers need to be, above all, patriots, otherwise the industry is not easy to raise. It is also necessary to understand the national importance of "long money". The compensation for the difficulties would be the sustainability of demand.

What is the essence of policy inefficiency in the economy of the end of the past and the beginning of the new century? This is question No. 1, and it is not so much about who is to blame. We are interested in the essence of the political paradigm developed by those who were "at the helm". Question №2 - what should be changed and how, apparently, it is necessary to do to raise the national industry, the production of clothing, footwear, leather goods, textiles, accessories, not least?

The answer to question 1 is simple - no one was going to develop a paradigm of economic policy aimed at radical transformation of the basis. The way of reforming (not without the help from outside) decided to choose from ready samples. The model was proposed to take the Swedish experience, the Polish "shock therapy", the reforms in Portugal and Argentina. Such innovators, brave scientists, wise organizers as Gaidar, Chubais, Koch, Burbulis did not come up with the idea, which usually starts a responsible owner - what I have to copy something.

Politics is not done according to the state of the senses. Like it or not - the level of everyday perception of the world. With this approach, it is harmful to be in the "political kitchen". Economic policies do not qualify as "good" or "bad", "effective" or "ineffective". It has the right to be called either "useful" or "harmful". The price of such a policy is too high, and the responsibility is not limited to the professional form. Politics is politics. It is antipolitical and unprofessional to make politics a source of one's own income.

Whatever the economic situation, it is extremely dangerous to absolutize the importance of economic criteria, to endow them with the property of 


\begin{tabular}{llllll} 
& ISRA (India) $=\mathbf{3 . 1 1 7}$ & SIS (USA) $=\mathbf{0 . 9 1 2}$ & ICV (Poland) & $\mathbf{= 6 . 6 3 0}$ \\
Impact Factor: & ISI (Dubai, UAE) $=\mathbf{0 . 8 2 9}$ & PUHЦ (Russia) $=\mathbf{0 . 1 5 6}$ & PIF (India) & $=\mathbf{1 . 9 4 0}$ \\
& GIF (Australia) $=\mathbf{0 . 5 6 4}$ & ESJI (KZ) & $\mathbf{8 . 7 1 6}$ & IBI (India) & $=\mathbf{4 . 2 6 0}$ \\
& JIF & $\mathbf{1 . 5 0 0}$ & SJIF (Morocco) $=\mathbf{5 . 6 6 7}$ & OAJI (USA) & $\mathbf{0 . 3 5 0}$ \\
\hline
\end{tabular}

universality. Engels strongly opposed attempts to reduce Marx's doctrine of social development to "economic materialism", "economic determinism". The economic basis is the basis of social organization, but not the system-forming factor of its improvement.

Society - a system of human relations, carried out in the dynamics of economic activity. Activity is a means of social life of people. Activities that necessitate different kinds of relationships - a way of manifestation and development of man. Relations are designed to ensure such human development. About the fact that the form of ownership should be changed, at the end of the XX century did not say only dumb, but that the relations born by the form of ownership, pull the distribution of the produced product, or its monetary equivalent, that the exchange can not be completely trusted to the market, control functions should be maintained for the state, rebuilt democratically, that in a perverse bureaucratic form the state remains a generator of corruption, tried to keep silent, understanding the delicacy of property reform.

The majority of the population does not have relevance in who the owner is, not everyone wants to try on the functions of the owner - to spin, spin, fight, risk. Distribution, on the contrary, concerns everyone, both poor and non-poor.

The most difficult component of economic reforms is to achieve satisfaction in society with the distribution of the national product. The health of society depends on this satisfaction, not on the form of ownership. And we have come to an important conclusion - the quality of reforms is evaluated not by the changes themselves, but by the ability to give social life the features of stability.

Integration, globalization is not a panacea for development. They do not cancel the competition, which are not the only winners. More losers. Hence the relevance of the old truth, the meaning of which became clear in dialectics. Movement in any conditions becomes self-movement. The Chinese rationally closed themselves and won. The victory ensured them: Eastern caution and skepticism about the merger. They realized before us that integration and globalization are types of "pyramids" and conditionally useful for national development. From the outside it might seem that the Chinese reformers abandoned the mentality of the curse: "to live you in time of change." From the inside, everything looked traditional - politicians did not betray a sharp movement of the national scale, hurried, but with constant binding of actions to the state economic order, reforms in the economy subordinated to traditional political dominants, did not repent and did not try to please. No one thought seriously about any economic shocks. Finance as a circulatory system of the economic organism was taken into the "state gloves", introduced tightening for economic and corruption crimes, equating many of them to dangerous actions against the state, did not invent new parties - updated the existing, as before, special attention was paid to personnel policy. The Chinese took into account the Soviet party experience of "growing" personnel, which was based on the principle of progressive promotion depending on business efficiency and lifestyle.

In seventy years of Soviet history there were isolated cases when random people were in the management of the economy. They could be just by chance, confirming their exclusivity, the capacity of the political personnel paradigm. Taking into account the economic disadvantages of excessive centralization in the management of the national economy, we can afford the following thesis - the socialist economy of the Soviet type was not rationally built, but it contained a significant reserve that enabled the new revolutionaries not to repeat the old Bolshevik techniques - to help one and Rob others.

The Bolsheviks in the image of revolutionaries look at all odious policy of nationalization of property in a more favorable light in comparison with those who in the 1990s squandered the national treasure and very reluctantly changes their interest in what is happening today. The result of the revolution of 1917 was the industrialization and rise of light industry, folk crafts, the result of the counter-revolution - 25-year depression of the economy, the struggle for the existence of textile, footwear, clothing production, the decline in the organization of training of qualified personnel across the spectrum - from workers to engineering. In such circumstances, it is time to abandon the abstract political ideals of the dem reformers and closely develop a "road map" of the revival of the light industry in the hope that the crisis emphasizes the relevance of the rationality of "brainstorming" in contrast to the "economic schools" in the trend. What is this "map" is based on the historical experience of the XX century, when all the major events occurred.

1. The priority should be sustainable interests of national promotion. I would very much like to say about development, but it is not available on a national scale now. You need to "lick your wounds." Today, the most economically optimistic assessment is within the framework of achieving stability of economic indicators stabilization. Doctors in such a situation are encouraging: the condition is "stable severe". Unfortunately, the economy cannot be put into an "artificial coma" that helps to overcome the crisis at the expense of more economical expenditure of vital forces. We are interested in the first point of the road map. Doctors strive to mobilize the vital potential of the body, to help reveal the reserve of the will to live. Our economy is able to fight for survival, it has a lot 


\begin{tabular}{llllll} 
& ISRA (India) $=\mathbf{3 . 1 1 7}$ & SIS (USA) $=\mathbf{0 . 9 1 2}$ & ICV (Poland) & $\mathbf{= 6 . 6 3 0}$ \\
Impact Factor: & ISI (Dubai, UAE) $=\mathbf{0 . 8 2 9}$ & PUHЦ (Russia) $=\mathbf{0 . 1 5 6}$ & PIF (India) & $=\mathbf{1 . 9 4 0}$ \\
& GIF (Australia) $=\mathbf{0 . 5 6 4}$ & ESJI (KZ) & $\mathbf{8 . 7 1 6}$ & IBI (India) & $=\mathbf{4 . 2 6 0}$ \\
& JIF & $\mathbf{1 . 5 0 0}$ & SJIF (Morocco) $=\mathbf{5 . 6 6 7}$ & OAJI (USA) & $\mathbf{0 . 3 5 0}$ \\
\hline
\end{tabular}

of smart, knowledgeable, dedicated patriots, however, with each lost year their number decreases. According to the doctor of Economics, Professor of the HIGHER school of Economics V. Inozemtsev - one of the permanent authors of the AIF, about 400 thousand people leave the country every year. Naturally, not all for permanent residence, someone to work under the contract, in search of temporary work. First of all, you need to help energetic people, to light the green light at the end of the tunnel. To rely on officials developed over a quarter-century type, who are confident that hanging over them was not the sword of justice, and a safe Deposit box of a senior bureaucrat to receive remuneration, do not have. Possible option - onf. The Russian President regularly communicates with its interested activists. Communication is productive.

Academician A. G. Aganbegyan testified that the year of economic recession due to poor management requires much more time to restore the economy. Act on the starting segment should be so that enough strength to finish and would remain for the next stage. We should not hope for great achievements. Wonderful transformations can be expected in private enterprise. There is a chance here. In the General process, the role of the case is insignificant. To refuse to believe in luck, however, is unwise. There is opinion, that "bad luck" those who bad luck. Successful alignment may induce through professional activity, character, faith in a successful outcome, and even in the highest justice. Faith, which accompanies the mind, has not prevented anyone from striving to do a good deed.

All inter-state unions must be considered solely in the national interest, otherwise you will lose. An economic agreement is an international condition, which is really to try to use for its own promotion, both at the level of the company and the industry. However, it should be understood that if you fail to benefit from the terms of the contract you, it will get your competitors, who turned out to be more savvy. A compromise option is not excluded, when the profit is mutual and temporarily divided in proportion to the participation. The main thing to know - the agreement in any form of competitors leaves competitors, it gives competition a civilized look, limiting arbitrary actions. For the leaders of China says production. In 2014, the Chinese sewed 14 billion pairs of shoes -2 pairs for each inhabitant of the Earth. Chinese leaders, therefore, at meetings, at the signing of the protocols I know the type. Our harder - in the absence of similar figures are waiting for assurances of friendship and mutual assistance. Good, good-neighbourly, mutually beneficial relations are the only real reality of the progressive movement. Everything else is virtual reality.

2. The stake on the full support of light industry, as well as most areas of investment of public funds (financial, legal, political, humanitarian), contains risk, but within acceptable values. History has tested Russia as an independent state, and as part of the USSR on the ability to create a variety of high-quality products of national demand in sufficient quantities. Strengths of domestic light industry products: material quality, hygiene, compliance with national ergonomic and climatic conditions, a variety of range. In the 1980 s, with the development of cooperation, there were positive changes in the design attitude. Clothing and footwear, since the 1930s, became available to all groups of the population.

In Russia, you can produce almost all kinds of materials needed for the light industry. Production of certain types of raw materials is limited in volume, which in principle is regulated by scientific and technological progress. The development of science and technology supplemented natural materials with artificial, synthetic ones. In the country there were scientific schools within agricultural production and light industry, the system of specialized vocational education was created. Personnel were trained in schools, technical schools, universities, some educational institutions disappeared in the course of democratic reforms, but the experience of training remained. He's not difficult to resuscitate. Preserved industrial centers, enterprises. Just in those places where the percentage of unemployed is high. The revival of light industry enterprises will lead to the activation of the socio-cultural environment, regional traditions, faith in the future of the population. People's social optimism will return.

In favor of purposefulness to develop the production of goods necessary to meet the physiological needs of man, are the size of the consumer market. They guarantee the stability of the production load orders for the relevant products.

3. The creative potential of specialists is still high. He's quite competitive. Domestic artists, designers, engineers, organizers have a high international rating. Often they are more and better known abroad than in their home country. Like all creative people, they seek to diversify the development of production, taking into account the specifics of the market, aware of the importance of monitoring the interest and opportunities of the mass consumer. We have moved away from state regulation of quantity, quality, price of manufactured products, which was quickly used by people random for the industry. Those who, having privatized enterprises, understood this as a way to improve personal income and sought to squeeze out the maximum margin, are guilty of the collapse of the industry no less than their "senior" partners, who determined the fate of the economy created by the people with the help of incompetent reforms. Oligarchs and oligarchic capitalism are also a historically developing 


\begin{tabular}{llllll} 
& ISRA (India) $=\mathbf{3 . 1 1 7}$ & SIS (USA) $=\mathbf{0 . 9 1 2}$ & ICV (Poland) & $\mathbf{= 6 . 6 3 0}$ \\
Impact Factor: & ISI (Dubai, UAE) $=\mathbf{0 . 8 2 9}$ & PUHЦ (Russia) $=\mathbf{0 . 1 5 6}$ & PIF (India) & $=\mathbf{1 . 9 4 0}$ \\
& GIF (Australia) $=\mathbf{0 . 5 6 4}$ & ESJI (KZ) & $\mathbf{8 . 7 1 6}$ & IBI (India) & $=\mathbf{4 . 2 6 0}$ \\
& JIF & $\mathbf{1 . 5 0 0}$ & SJIF (Morocco) $=\mathbf{5 . 6 6 7}$ & OAJI (USA) & $\mathbf{0 . 3 5 0}$ \\
\hline
\end{tabular}

phenomenon. It is a mistake to reject the socially positive meaning of their existence. It is one thing for oligarchs-financiers, oligarchs-media moguls, who made fortunes on speculation, mediation, wild production of carbon raw materials, another - those who developed real production with a significant share of added value, i.e. thought about the future.

After the Gaidar economic forum and the Congress of Industrialists (2016), the oligarch O. Deripaska spoke very politically Mature: "2016 is the last year when the state will be able to use the reserves to help production, from next year we must begin to help the state." There is confidence that the opinion of one of the most active and experienced domestic oligarchs is not his exclusive view on the interaction of the state and economic entities.

Escape from Russia in the future - the lot of those who are opposed to Russia, hiding in the "white furry fur" abstract democratic idea of world unity, along with his greed. In the West, they are not needed, their finances are in demand there - not as impressive by Western standards as in the plundered Fatherland, and anti-Putin views.

The history of Russia is rich in examples of smart, Patriotic economic policy, namely large owners who were ahead of the actions of public administration bodies, endowed with professional political responsibility for the development of production. It seems that those who are directly responsible for financial and production policy, having studied the historical experience, are waiting for the production itself to put forward "locomotives" to promote the existing composition. D. Gref, who came out of the named sector of the government to the heads of Sberbank, openly said at the said "Gaidar Forum" about the need for an active government policy to plan to overcome the crisis in the economy, investment of Finance in real production, control over the use of state loans by banks. Frightened by the "wrong" - not a cyclical crisis, banks do not want to risk even "short" loans in the interests of production. They "protect" speculators in the market and became ordinary speculators, blowing in the financial turnover of state loans, leaving manufacturing enterprises without credit, or prescribing lethal rules of calculation.

Light industry enterprises in this situation is somewhat easier to act. First, the replacement of equipment is not so costly. For example, it costs $\$ 5$ million to equip a physical laboratory with basic modern equipment. Secondly, you can do "short" money, which joins the interests of the financier and the manufacturer. But at the same time, light industry enterprises are more dependent on the rapidly changing market conditions, therefore, it is necessary to be able to spin quickly, to be able to use centrifugal forces - to diversify production. "Diversification" is a multidisciplinary word. In dictionaries emit 4-5 meanings. In the context of our study, three are relevant: "Diversification of production" as the spread of economic activity in new areas, the branching of production, the expansion of the range of products; type of marketing strategy, providing for the expansion of products, the production of which is not associated with the main direction of production activities of the enterprise and credit diversification the distribution of investments.

Diversification currently "works" in the mode of "most favored nation", of course, with a creative approach, balanced risks and skillfully built monitoring. We mean the beginning of the transition in the development of mass production from the first type to the second - "lean production", which can be translated as "sparing" or "prudent production".

This type of production fundamentally changes the very purpose of the production process. At the same time, the traditional task of manufacturing a large number of similar products that meet the requirements of regulatory documents, from which the consumer must choose the most suitable for him, is replaced by the task of manufacturing exactly such a product, which is necessary for this consumer and in the required volume and at a certain time

A new type of organization of mass production shifts the study of planning optimization to the study of the originality of market demand as a total expression of individually different wishes. The market is personified depending on a large number of indicators involved, which requires increased diversification of production. The nature of the market is changing, and entrepreneurs are obliged to respond to this transformation adequately and quickly.

To change the paradigm that integrates the policy of organization and management of production, its restructuring is not enough, but a serious modification in the planning of enterprises has long been necessary. And it began, maybe still in the minds of producers and owners, but this is a natural introduction to practice. The study of the mosaic of market demand complicated the search for new markets. The desire to capture the market in 2016 is unreasonable, as well as the dream to overtake China, and we can catch up only in a dream. Fortunately, you can surpass in different ways. The most primitive option is to do something more, more promising - to get ahead, to squeeze into the structure of the market, where its density is not so great. The General Director of the Novosibirsk company "clothes Factory" N. Treschev sure to really squeeze into the ranks of the production of "high quality sewn" from a fairly expensive fabrics, interesting design. In the 1990s, Russia was flooded with "Bush legs", and nothing seemed to be able to displace them from the market. At the present time they are not even remembered. 


\begin{tabular}{llllll} 
& ISRA (India) $=\mathbf{3 . 1 1 7}$ & SIS (USA) $=\mathbf{0 . 9 1 2}$ & ICV (Poland) & $\mathbf{= 6 . 6 3 0}$ \\
Impact Factor: & ISI (Dubai, UAE) $=\mathbf{0 . 8 2 9}$ & PUHЦ (Russia) $=\mathbf{0 . 1 5 6}$ & PIF (India) & $=\mathbf{1 . 9 4 0}$ \\
& GIF (Australia) $=\mathbf{0 . 5 6 4}$ & ESJI (KZ) & $\mathbf{8 . 7 1 6}$ & IBI (India) & $=\mathbf{4 . 2 6 0}$ \\
& JIF & $\mathbf{1 . 5 0 0}$ & SJIF (Morocco) $=\mathbf{5 . 6 6 7}$ & OAJI (USA) & $\mathbf{0 . 3 5 0}$ \\
\hline
\end{tabular}

Our poultry industry won. Why should we be afraid of Chinese consumer goods intervention? We need protectionist measures within the WTO, the SCO, but in principle they are not the essence of the matter. Movement is productive due to its independence from external factors. Sustainable development is a consequence of self-movement. If cash conditions do not contribute to the development, it is necessary to look for reserves in the process, "removing" the negative effect of external circumstances.

The state is obliged to make a turning point in the fall of the prestige of professions related to the light industry, to create attraction for those who decided to devote themselves to this interesting business. Owners are looking for reserves to raise wages. It is on the VAT in 2018 did not exceed 16 thousand rubles, which is half the salary of the average for the region. The Director of the group of Shoe companies A. Titov sees the output in the transition of production to automated systems. Last year, the companies spent 350 million rubles on the purchase of Italian and Taiwanese equipment. the Forecast of development of production of A. Titov connects with increase of production of footwear of a mid-price segment that allowed to attract qualified specialists, to carry out retraining of a personnel backbone and to increase a salary on average to 35 thousand rubles. In favor of the forecast, A. Titov also works to reduce the presence of Turkish products in the domestic market.

We must also take into account the fact that China's economic growth will inevitably lead to an increase in wage costs. This will emphasize the relevance of logistics calculations. As a result, the Chinese will lose their economic attractiveness, and it will be possible to compete with them in the segment that interested A. Titov. Russian Industrialists have such a trump card as their raw materials of natural origin. We hope that the promised investments in agricultural production will reach farms and fields.

The market for the light industry is growing due to social and cultural progress, in particular, due to the development of professional sports, increasing the demand for those who choose sports as a way to a healthy lifestyle. At the end of 2015, the newspaper "Sportexpress" published an interview with the Chairman of the Russian Outdoor Group A. Grebtsov. "The outdoor market is served by mountaineering, tourism, extreme sports, special forces, rescue units, polar services and troops. These are areas that require heavy-duty, frost-resistant, waterproof equipment that meets the latest international standards of safety and comfort." A. Grebtsov reported interesting details, in particular, he compared the technological base of production of quality products in Russia, Europe and Asia. We are "somewhat behind", in his estimation, from the Asian potential, but with Europe "we Can definitely compete... in Russia there are about 30 (!) companies that know how to sew well." After the introduction of the import ban for the state order and the state defense order, the share of materials from the member States of the Customs Union supplied to the law enforcement agencies of the country increased from $50 \%$ in 2018 to $83 \%$ in 2018 . In 2018 , the trend of increasing the percentage of materials produced on the territory of CPAS used for the production of clothing and equipment should be of the order of 85 $90 \%$. The reversal of the state order in the direction of the domestic production opportunities for allied chemical industry (raw material for yarns, fabrics, membranes, insulation). Grow the production of fabrics, tailoring, that will pull the design of the equipment. D. Manturov believes that it is important to consolidate the achieved results:

- $\square$ make clear to large retail chains the importance of the acquisition and placement of products in Russia, of course, given they are of good quality;

- $\square$ to place the first orders for the production of those "who already stood on his feet and knows how to sew". They proved their worth;

- $\square$ assist companies with obtaining European certification of materials, otherwise foreign firms will not be interested in them, and the goods produced here will not get to the West;

- $\square$ actively support companies with collective stands at international exhibitions;

- $\square$ provide subsidies to such enterprises for loans for the purchase of raw materials. The share of these loans in total lending should be between 50 and $85 \%$;

- $\square$ exempt modern imported equipment from import duties and VAT. Machines used in sewing shops, $90 \%$ imported;

- $\square$ introduction of subsidized leasing.

As you can see, D. Manturov's program systematizes the main and primary steps in the direction of the light industry to regain its former importance. But Heraclitus was right in saying that one cannot enter the same river twice. The rise of the light industry should be carried out on a new technological, economic and legal basis.

4. The reforms of the $1990 \mathrm{~s}$ opened the floodgates for a flood of Chinese goods. The purchasing power somehow reached its price. Shuttles trampled on the border with the Eastern neighbor whole avenues, and in fact with them and thanks to them formed a cultural perception of the goods. First bought from despair, then, because cheap. And instilled a primitive taste, bordering on bad taste. In modern times, it is necessary to work thoroughly on the culture of consumer demand - to educate the buyer. We have repeatedly stressed in our publications that the understanding of the quality of natural and artificial phenomena is not identical. Consumer goods 


\begin{tabular}{llllll} 
& ISRA (India) $=\mathbf{3 . 1 1 7}$ & SIS (USA) & $=\mathbf{0 . 9 1 2}$ & ICV (Poland) & $=\mathbf{6 . 6 3 0}$ \\
Impact Factor: & ISI (Dubai, UAE) $=\mathbf{0 . 8 2 9}$ & PUHL (Russia) $=\mathbf{0 . 1 5 6}$ & PIF (India) & $=\mathbf{1 . 9 4 0}$ \\
& GIF (Australia) $=\mathbf{0 . 5 6 4}$ & ESJI (KZ) & $=\mathbf{8 . 7 1 6}$ & IBI (India) & $=\mathbf{4 . 2 6 0}$ \\
& JIF & $\mathbf{1 . 5 0 0}$ & SJIF (Morocco) $=\mathbf{5 . 6 6 7}$ & OAJI (USA) & $\mathbf{0 . 3 5 0}$ \\
\hline
\end{tabular}

are produced by man and for man. It alienates the human essence, including the socio-cultural status of the individual. Consequently, the understanding of quality should include the subjective perception of the properties of the goods through feelings and reflection. Perception of quality should not be allowed to "drift", to give sensual elements or simplistic thinking. It is important to learn not only the art of modern design, to sew shoes, clothes, it is necessary to help the consumer to understand all this, to direct his aesthetic and hygienic ideas, to make him empathize, to feel satisfaction from the purchased goods.

\section{Conclusion}

The wise Buddha laid down four key steps in the eightfold path: correct understanding; making the right decision; finding the right words and, finally, the right actions aimed at implementing the right decisions. The fate of the light industry now depends on what will be this last step. Its execution is a function of the Government. The political paradigm is very simple - we should not compete with anyone in the struggle for the world market, especially with the Chinese. The Chinese rightfully want to put on and dress the whole world. One fifth of the world's population lives in China. Our task is quite different. We need to make sure the Chinese don't put on shoes or dress us. Translate consumer demand on the domestic production, to sell the goods produced in the country. The task is quite within our power, as the manufacturers say. And the Government needs to do its direct work consistently and in a timely manner, and not deceive the public in the light industry, as happened with the sewing of school clothes.

\section{References:}

1. Aleshin, B. S., et al. (2004). Philosophical and social aspects of quality. (p.438). Moscow: Logos.

2. Cobb, B., \&Gray, E. (1997). Acceptance and continuous development of the Japanese philosophy of total quality management. Tr. 4020 Congress of the EOC. (p.327). Berlin.

3. Prokhorov, V. T., et al. (2017). The concept of import substitution of products of light industry: background, challenges, and innovations: monograph / under the General editorship of Dr. sci. prof. V. T. Prokhorova (Eds). Institute of service and entrepreneurship (branch) of the don state technical University. (p.334). Mines: Isoip (branch) of DSTU.

4. Prokhorov, T. V., et al. (2015). The range and assortment policy: monograph / under the General editorship of Dr. sci. Sciences, Professor V. T. Prokhorov (Eds.). Institute of the service sector and entrepreneurship (Phil.) Fader. state budget. educated. institutions of higher. professional education "don state technical. UN$\mathrm{t}$ " in mines Growth. region (Isoip (branch) of DSTU). (p.503). Novocherkassk: URGU (NPI).

5. Surovtseva, O. A., et al. (2018). Management of real quality of production instead of advertizing through motivation of behavior of the leader of collective of the enterprise of light industry: the monograph / under the General edition of Dr.
Techn. prof. V. T. Prokhorova (Eds.). Institute of service and entrepreneurship (branch) of the don state technical University. (p.384). Novocherkassk: URGU (NPI).

6. Prokhorov, V. T., et al. (2018). Competitiveness of the enterprise and competitiveness of production - guarantee of successful import substitution of the goods demanded by consumers of regions of southern Federal district and skfo: collective monograph / under the General edition of Dr. Techn. prof. V. T. Prokhorova (Eds.). Institute of service and entrepreneurship (branch) of the don state technical University. Mines: Isoip (branch)of DSTU.

7. Prokhorov, V. T., et al. (2017). The concept of import substitution of products of light industry: background, challenges, and innovations: monograph under the General editorship of Dr. sci. prof. V. T. Prokhorova (Eds.). Institute of service and entrepreneurship (branch) of the don state technical University. (p.334). Mines: Isoip (branch) of DSTU.

8. Surovtseva, O. A., et al. (2018). Management of real product quality and not advertising through the motivation of the leader of the team of the enterprise of the legka industry: monograph / under the General ed. Dr. Techn. prof. V. T. Prokhorova (Eds.). Institute of service and 


\begin{tabular}{llllll} 
& ISRA (India) $=\mathbf{3 . 1 1 7}$ & SIS (USA) & $=\mathbf{0 . 9 1 2}$ & ICV (Poland) & $=\mathbf{6 . 6 3 0}$ \\
Impact Factor: & ISI (Dubai, UAE) $=\mathbf{0 . 8 2 9}$ & PUHL (Russia) $=\mathbf{0 . 1 5 6}$ & PIF (India) & $=\mathbf{1 . 9 4 0}$ \\
& GIF (Australia) $=\mathbf{0 . 5 6 4}$ & ESJI (KZ) & $=\mathbf{8 . 7 1 6}$ & IBI (India) & $=\mathbf{4 . 2 6 0}$ \\
& JIF & $\mathbf{1 . 5 0 0}$ & SJIF (Morocco) $=\mathbf{5 . 6 6 7}$ & OAJI (USA) & $\mathbf{0 . 3 5 0}$ \\
\hline
\end{tabular}

entrepreneurship (branch) of the don state technical University. (p.384). Novocherkassk: URGU (NPI).

9. Prokhorov, V. T., et al. (2018). Competitiveness of the enterprise and competitiveness of production - guarantee of successful import substitution of the goods demanded by consumers of regions of southern Federal district and skfo : the collective monograph / under the General ed. prof. V. T. Prokhorova (Eds.). Institute of service sector and entrepreneurship (branch) of don state technical University. (p.337). Novocherkassk: Lik.

10. (2015). GOST R ISO 9000-2015 of the quality management System. The main provisions and Glossary (Amendment)

11. (2015). GOST R ISO 9001-2015 of the quality management System. The requirements of GOST R ISO 9001-2015 National standard Russian federation state quality management date of introduction 2015-11-01

12. (2016). GOST R 57189-2016/ISO/TS 9002:2016. National standard of the Russian Federation. Quality management system. Guidelines for the application of ISO 9001:2015 (ISO/TS 9002:2016, IDT)" (approved. By the order of Rosstandart on 25.10.2016 N 1499-St).
[Official website of the International organization for standardization (ISO)] URL: http://www.iso.org/iso/ru/catalogue detail?csnu mber $=52844$

13. (2010). GOST R ISO 9004-2010. Managing for the sustained success of an organization. Quality management approach.

14. Vdovin, L. P., Prokhorov, V. T., Osin, T. M., Meleshko, E. N., \& Osaca, N. I. (2014). A means of providing sustainable technical and economic indicators of the footwear enterprises in the regions of SFD and NCFD/ the memory of V. A. Fokina is dedicated to: SB.nauch. articles and memories. (pp.32-41). Moscow: MSUDT. Part 3.

15. Train, Y. M., Polukhina, S. Y., Osina, T. M., Kompanchenko, E. V., \& Meleshko, E. N. (2014). About search of effective means of influence of cash flows on results of activity of the Shoe enterprises of regions of southern Federal district and skfo. Innovative development of light and textile industry" (INTEX-2014): abstracts of the all-Russian scientific student conference. (p.116). Moscow: FGBOU VPO "MSUDT". 